\title{
Nāgārjuna and Sātavāhana
}

\section{YAMANO Chieko}

Both Chinese and Tibetan sources include some amount of hagiography of Nāgārjuna and hence have been read as reference sources for re-establishing his historical activities or attesting to the authenticity of his writings. Many scholars have focused on the accounts of his contemporaneousness with King Sātavāhana or King Kaniṣka and the accounts of his activities as an ācārya of a king. The rest of his legendary accounts have been considered as the result of a later addition or the interfusion of the accounts of another Nāgārjuna and hence have been removed from the object of consideration. It seems that the re-establishment of his historical activities using hagiographical accounts is a crucial problem. Archaeological sources that testify the existence of the historical Nāgārjuna remain undiscovered. In fact, to date, there exists a controversy regarding the period in which Nāgārjuna livedfrom the first century to the third century. I begin this paper by indicating the limitations of re-establishing his historical activities using these hagiographical accounts; next, by focusing on the legends of Nāgārjuna and Sātavāhana, I examine the formation and development of the hagiography of the former separate from historical viewpoints.

The attempt to identify King Sātavāhana-who was Nāgārjuna's patron according to Xuanzang (602-664) - began with Indian archeology in the late nineteenth century. In the Ancient Geography of India, A. Cunningham considered King Sātavāhana as Gautamīputra Sātakarṇi (r.114-135) ${ }^{1)}$ who ruled over Deccan in the second century ${ }^{2)}$. After Cunningham, J. Burgess established the dates of successive kings of the Sātavāhana dynasty based on archaeological sources from Amarāvatī and Jaggayyapeta, and he assumed Yajñașrī $(\text { r.178-200) })^{3)}$ or Pulumāyi III (r.215-220) ${ }^{4)}$ to have been Nāgārjuna's patron ${ }^{5)}$. As the investigation of the remains of Amarāvatī, Jaggayyapeta, and Nāgārjunakoṇ̣a revealed the chronology of ancient South India, the question concerning Nāgārjuna's patron was sometimes addressed. The attempt to identify King Sātavāhana has continued from Cunningham and Burgess until today ${ }^{6)}$. Although previous studies adopted an approach based on ar- 
chaeological sources, they assumed that the accounts of Nāgārjuna's contemporaneousness with King Sātavāhana - which was made popular from the seventh century onwardsreflect some historical facts. In addition, it should be noted that no existing archaeological source provides substantiation for the relation between Nāgārjuna and a king of the Sātavāhana dynasty ${ }^{7)}$.

King Sātavāhana in Indian literature

Sātavāhana is the name of the dynasty that ruled over Deccan from the first century ${ }^{8)}$ to the third century. Pratișthāna (modern Paithan), the capital of the dynasty, was located in the upper reaches of the Kṛ̣na river. The Sātavāhana dynasty is also referred to as the 'Andhra dynasty' in Purāṇic literature because it ruled even the Andhra region at a later time. Sātavāhana is known by various names such as Śātavāhana, Sālavāhaṇa, Sālāhaṇa, Sālivāhana, Sādavāhana and Śătakarṇi. Additionally, Sātavāhana is known as Hāla in narrative literature. 'Hāla' in Mahārāsțtī corresponds to the word 'sāda' in Sanskrit, which is an abbreviation for Sādavāhana ${ }^{9)}$. Although these appellations do not precisely indicate a personal name, a king named Sātavāhana or Hāla appears sometimes in narrative literature. Particularly, King Hāla is known as the compiler of the Sattasā̄, an anthology of Mahārāșțī poems. Therefore, Sātavāhana or Hāla is described as a king who has great knowledge of literature. Although King Hāla is recorded in Purānic literature as the eleventh king of the Sātavāhana dynasty ${ }^{10)}$, it seems that King Sātavāhana or Hāla is a legendary king and that he cannot be identified with a historical person.

In Buddhist literature, King Sātavāhana was mentioned relatively early in the Chinese version of the Mahämegasütra translated by Tanwuchen (385-433). It was said that a king named Sătavāhana would appear in South India 1200 years after the death of the Bud$\mathrm{dha}^{11)}$. Later, the Jain authors of the medieval Prabandha literature wrote numerous of tales of King Sātavāhana ${ }^{12)}$.

\section{Legends of Nāgārjuna and Sātavāhana}

The earliest accounts of the relation between Nāgārjuna and Sātavāhana appeared in the Da Tang Xiyuji written by Xuanzang and the Harșacarita written by Bāṇabhatta (c.606-647). Because the former has already been discussed in other papers ${ }^{13)}$, I focus on the latter and related texts in this paper. Bāṇabhatta narrated that Nāgārjuna, when visiting a Nāga land, 
received a wreath of pearls from the Nāga king Vāsuki and presented it to King Sātavāhana upon his return. This story is inserted as an episode in a scene in which King Harșa was presented with this precious treasure by a Buddhist mendicant.

sa ca tair muktāphalaị pātālatale 'pi tārāganam iva darśayadbhir ekāvalìm akalpayat / cakāra ca mandākinīti nāma tasyāh / sā ca bhagavatah somasya sarvāsām oṣadhīnām adhipateh prabhāvād atyantavișaghnī himāmrtasambhavatvāc ca sparśena sarvasattvasaṃtāpahārin̄ībabhūva/yatah̆ sa tām sarvadā viṣoșmaśāntaye vāsukih paryadhatta/samatikrāmati ca kiyaty api kāle kadācin nāmaikāvalìm tasmān nāgarājān nāgārjuno nāma nāgair evānītah pātālatalam bhikṣur abhikșata lebhe ca/ nirgatya ca rasātalāt trisamudrāalhipataye sātavāhananāmne narendrāya suhrde sa dadau tām $/{ }^{14)}$

In a Nāga land, he (Vāsuki) made a wreath of those pearls that shone like stars and named it Mandākinī. Because it has the power of holy soma, the lord of all medical herbs, and because it is made from cool (or lunar) amrta, which is an efficacious antidote, one who touches it gets healed of all sorts of fever (or pain). Vāsuki always wore it to reduce fevers. As time passed on, one day, a Buddhist monk named Nāgārjuna was brought to the Nãga land by the Nāgas ; he asked the Nāga king for the wreath of pearls and received it. When he returned from the Nāga land, he gave it to his friend King Sātavāhana, the lord of three oceans.

As for Nāgārjuna's visit to a Nāga land, Kumarajīva (350-409) has already mentioned in the Biography of Nāgārjuna that Nāgārjuna, who was invited to a Nāga land by Nāgabodhisattva, received the Vaipulyasütra there ${ }^{15)}$. Wang Xuance, who was sent to India as a diplomat during the seventh century, reported that there was a stūpa by the seaside located $100 \mathrm{li}$ from the capital of Kosala. A king built another stūpa to cover the jeweled stūpa that was presented to the king by Nāgārjuna-who, in turn, had received it from a Nāga king in a Nāga land ${ }^{16)}$. In Tibetan tradition, Bu-ston mentioned that Nāgārjuna, who invited to a Nāga land by two Nāga children, brought clay to make a stūpa and a sūtra, which contains one hundred thousand verses ${ }^{17)}$. Although the story that Nāgārjuna presented the precious pearls to King Sātavāhana is unique to the Harșacarita, the plot in which the gift is given to Nāgārjuna by a Nāga king and further gifted to a king is similar to Wang Xuance's report. In this case, this gift is the wreath of pearls that is made from amrta and can relieve all sorts of pain. The power of the Nāga that is connected closely to vital energy becomes a mediator between Nāgārjuna and Sātavāhana.

The birth of Sātavāhana is sometimes narrated as being related to the Nāga in Indian literature. In the Vikramacarita, although being a later text ${ }^{18)}$, it is mentioned that he is a son of the Nāga king Śeșa. In this story, Sālivāhana who was supported by his father-Nāga 
King Śeșa-attacked and defeated the army of King Vikrama of Ujjayini. The Nāga king breathed life into a doll army and scared away the enemy army with his Nāga soldiers for Sālivāhana ${ }^{19)}$. The similar episode appears even in the Caturașitisiddhapravrtti, wherein Nāgārjuna, instead of the Nāga king, provided an army to Sālabhanda. He breathed life into the trunk of a tree and transformed it into an elephant vehicle for the king ${ }^{20)}$. Again, it should be noted that the power of the Nāga that provides vital energy becomes a mediator between Nāgārjuna and Sātavāhana.

The birth of Nāgārjuna is also narrated as being related to the Nāga in Jain Prabhanda literature. In the Prabhandakośa, he is said to be born to the Nāga king Vāsuki and a human princess of Satruñjaya. The Năga king nurtured his son with blind parental love and fed him various potent herbs; therefore, Nāgārjuna attained many siddhis and became a guru of King Sātavāhana ${ }^{21)}$. In Jain tradition, Nāgārjuna is known as a disciple of Pādalipta. Phyllis Granoff noted that Pādalipta is also connected with the Nāga and that the Năga's magical power is one of the factors that link Nāgārjuna to Pādalipta ${ }^{22)}$. Thus, the hagiographies of Nāgārjuna have been developed by linking various components and figures in legends with Năga as the motif.

Finally, the honorific title 'trisamudrādhipati', which appeared in the Harșacarita, indicates the lord of three oceans; the West Sea, the South Sea and the East Sea, that is, the conqueror of Deccan. Since a similar honorific title, which is added to the name of Gautamīputra Sātakarṇi, appears in the Nāsik inscription ${ }^{23)}$, some scholar considered King Sātavāhana in the Harṣacarita to be Gautamīputra Śătakarṇi ${ }^{24)}$. However, we must question the need to identify a legendary figure among historical characters. The hagiographies of Nāgārjuna have continuously developed and transformed through linkage of Nāga images within the world of storytelling in Deccan. Although it is almost impossible to re-establish Nāgārjuna's historical activities using these hagiographies, they provide rich information on cultural circumstances of the place wherein the story is told.

\section{Notes}

1) Dated by Burgess

2) A.Cunningham, The ancient geography of India, (Trubuer, 1871):595-596

3) Dated by Burgess

4) Dated by Burgess 
5 ) J.Burgess, "The Buddhist stupas of Amaravati and Jaggayyapeta in the Krishna District, Madras Presidency, surveyed in 1882", Archaeological Survey of Southern India v. 1 (1887): 8

6 ) The following are the various opinions on the identification the king.

Gautamīputra Śătakarṇi : A.Cunnungham [1871] P.S.Sastri [1954] L.Joshi [1965]

K.V. Ramanan [1966] L.Kawamura [1975] David J. Kalupahana [1992]

Vāsișthīputra Pulumāyi, : A.K.Warder [1967,1974]

Gautamīputra Sātakarṇi or Vāsișṭhīputra Pulumāyi, : S.Ichimura [1992]

Yajñaśrī : M.Winternitz [1920]

Vijayaśrī : R.H.Robinson [1967] J.Waleser [2005]

Yajñaśrī or PulumAyi III : J.Burgess [1887]

Vijayaśrī 〜 Ikṣvāku : I.W.Mabbett [1998]

7) An inscription found from near the Jaggayyapeta stūpa that records the name of Nāgārjuna. However, the inscription is traced back to the fifth and sixth centuries.

8 ) The Sātavāhana dynasty began with King Simuka, who is said to have lived in some period between the third century B.C. and the first century B.C.; however, it seems that the dynasty came to power in the first century B.C.

9) Lilavai : a romantic Kavya in Maharastri Prakrit of Kouhala with the Sanskrit Vrtti of Kouhala, Edited by A. N. Upadhye; Singhi Jain ser. 31 (Bharatiya Vidya Bhavan, 1966): 46-49

10) Vishnu prāna : the $11^{\text {th }} \mathrm{King}$, Bhāgavata prāna: the $9^{\text {th }} \mathrm{King}$, Vãyu prāna: the $10^{\text {th }} \mathrm{King}$

11) 大正蔵 $12.1099 \mathrm{c}-1100 \mathrm{a}$

爾時一切南方天子. 復以華香供養世尊白仏言. 世尊. 如是弟子. 何時当出在何国土名 字何等. 仏言. 善男子. 我涅盤後千二百年. 南天竺地有大国王. 名乷多婆呵那. 法垂 欲滅餘四十年. 是人爾時当於中出講宣大乗方等経典. 拯抜興起垂滅之法. 広令是経流 布於世.

12) Purātanaprabandhasañgraha, Prabandhacintāmani, Prabandhakośa, Prabhāvakacarita

13）山野智恵「ナーガールジュナとラサーヤナ」『智山学報』53 (2004)

14) The Harshacarita of Banabhatta, Edited by P.V. Kane (Motilal Banarsidass, 1965) : 137

15）大正蔵 $50.184 c, 186 a$

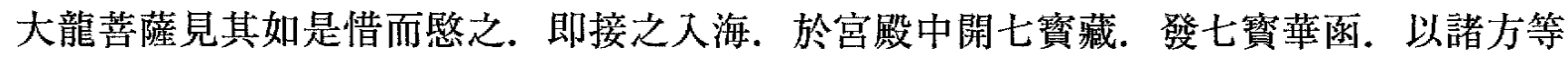
深奧經典無量妙法授之. 龍樹受讀九十日中通解甚多. 其心深入體得寶利. 龍知其心而 問之日. 看經遍未. 答言. 汝諸函中經多無量不可盡也. 我可讀者已十倍閻浮提. 龍言. 如我宮中所有經典. 諸處此比復不可數. 龍樹既得諸經一相深入無生二忍具足. 龍還送 出於南天竼.

16) This report is quoted in the Fa-Yuan Zhu-Lin. 大正蔵 53.589a

西域志云. 波斯匿王都城東百里大海邊有大塔. 塔中有小塔. 高一丈二尺. 裝䁬珼飾之. 夜中毎有光曜如大火聚. 云佛般泥洹五百歳後. 龍樹菩薩入大海化龍王. 龍王以此寶塔 奉獻龍樹. 龍樹受已將施此國。王便起大塔以覆其上. 自昔以來有人求願者. 皆吤頭燒 香奉獻華蓋. 其華蓋從地自起俳徊漸上. 當塔直上乃至空中. 經一宿變滅. 不知所在.

17) The collected works of Bu-ston, Edited by Lokesh Chandra: Ya.99b 
de'i tse byis pa gnyis chos mnyan cing sa 'og tu song ba la su yin dris pas klu yin zer ba la slob dpon gyis gnod sbyin gyi 'dam khyer la shog gsungs pas. de dag gis klu'i rgyal po la zhus pas slob dpon spyan drongs zer te sbyan drangs pas don du 'gyur bar mkhyen nas klu'i yul du byon nas chos gsungs so. de'i tse klus bzhugs par zhus pas nga mchod rten bye ba bzhengs pa' $i$ 'dam ' tsol ba dang 'bum gdan 'dren du 'ongs kyi bsdad mi khom. phyis 'ong srid gsungs te 'dam mang po dang. 'bum dang yi ge nyung ngu yang gdan drangs te. 'bum gyi zhabs nas bag tzam klus ma bskur zhes grag go.

18) It is dated to the forteenth century - the sixteenth century by Ludwik Sternbach.

19) Vikrama's adventures: or The thirty-two tales of the throne, Edited by Franklin Edgerton, Harvard oriental series vol. 27 (Harvard University Press, 1926) : 176-184

iti tadvacanāt sadyo roșāruṇitalocanah sasāinyo niragād rājā nihantum śālivāhanam/ pratișṭhānạ̣ samāsādya vikramādityabhūbhuji kṣaṇaṃ tișṭhati sāinyena bhagnās toraṇamālikāh/ atrāntare sametyā 'śu pāurāiḥ parivṛtạ̣ śsiśụ alabdhaśaraṇas tasya śeșạ̣ pitaram asmarat/ tena krị̄̂ākrtạ̣ sarvaṃ gajavājipadātikam mahāpralayasaṃtrāsasaṃnaddham abhavad balam// *snip* so 'pi jañgamatām āpa tenā 'sau sālivāhanaḥ/ tato yuddham avartișța sāinyayor ubhayor api// vikramārkabalam śeșapreșitā jihmagā yayuh/ plușțạ tan mānuṣam sāinyam āśîvașavișāgninā// kva divyasattvāh phaṇinah svalpaprāṇāh kva mānușāh/

20) Abhayadattașrī(c.11C),Caturașitisiddhapravrtti : 北京 . rgyud-'grel Lu.20a-b slob dpon gyis nga 'phags pa klu sgrub yin te khyod khyis ngo shes sam gsungs pas. gtam ni thos te ngo mi shes zhus so. slob dpon gyis ba lang rdzi de la khyod khyis nga chu las bsgral ba" i rngan pa ci dgos pa gter ba yin no. zhes gsungs pas. ba lang rdzi na re. bdag la rgyal po 'ong ba'i thabs geig zhu zer nas. slob dpon gyis sa phyogs de na shing sa' la'i sdong po gcig 'dug pa la chu stor bas shing de de ma thag glang po cher gyur nas rgyal po'i bzhon pa byas. dmag tsogs dgos zhu ba la glang po ches 'khun pa na dmag 'ong ba yin gsung ba de bzhin du byung ste. rgyal po'i ming sa' la bha ndha zhes bya la btzun mo'i ming si nd'i zhes bya bar gyur to. gnas grong khyer bha hi ta na zhes bya ba'i yul khyad par 'phags pa cig grub ste. rgyal po la khral 'jal ba'i grong khyer 'bum tso brgyag cu rtza bzhi la dbang byed pa'i rgyal por byas nas.

21) Prabandhakośa of Rājaśekharas̄ūri, Edited by Jina Vijaya: Singhi Jain ser. 6 (Adhisțhātāsinnighì Jauna Jñānapītha, 1935): 84

ḍaṇkaparvate surāṣțrābhūṣaṇaśatruñjayagirišikharaikadeśarūpe rājaputraraṇasiṃhasya bhopalanāmnīm putrīṃ rūpalāvanyyasampūrṇāṃ paśyato jātānurāgasya tāṃ sevamānasya vāsukināgasya putro nāgārijunanāmā jātah̆ sa ca janakena putrasnehamohitena sarvāsām mahauṣadhīnāṃ phalāni mūlāni dalāni ca bhojitaḥ/ tatprabhāvena sa mahāsiddhibhiralañkṛtạ̣ siddhapurușa iti vikhyātaḥ/ pṛthvīm vicaran pṛthvīsthānapattane sātavāhanasya rājñaḥ kalāgurur jātah̆/

22) Phyllis Granoff, "Jain Biographies of Nagarjuna : Notes on the Composing of a Bioraphy in Medieval India", Monks and Magicians : Religious biographies in Asia (Mosaic Press, 1988): 45-66

23) tisamudatoyapītavāhana

24) L.Joshi, "Life and Times of Madhyamika Philosopher Nagarjuna", Mahabodhi 73.1-2 (1965): 
42-49

K.V. Ramanan, Nāgārjuna's Philosophy, as presented in the Mahāprajñāpāramitāśāstra (Motilal Banarsidass, 1966) : 25-30

〈key words〉 Harșacarita, Vikramacarita, Prabandhakośa

(Researcher, Rengeji Institute of Buddhist Studies)

\section{新刊紹介}

財団法人 仏教伝道協会 英訳大蔵経翻訳叢書

\section{SHŌBŌGENZŌ: THE TRUE DHARMA-EYE TREASURY VOLUME 1}

\section{(正法眼藏 第一巻)}

Translated by Gudo Nishijima \& Chodo Cross

(Reprint of the book published by Windbell Publications in 1994.)

B5 変形判・定価 6,500 円 